\title{
Reputational Risk and Conflicts of Interest in Banking and Finance: The Evidence So Far
}

\author{
Ingo Walter*
}

This version: 9 December 2006

\begin{abstract}
This paper attempts define reputational risk in financial intermediation and to identify the proximate sources of reputational risk facing financial services firms. It then considers the key drivers of reputational risk in the presence of transactions costs and imperfect information in financial markets, surveys empirical research in the literature on the impact of reputational losses imposed on financial intermediaries, and presents some new empirical findings. The paper then develops the link between reputational risk and exploitation of conflicts of interest in financial intermediation, arguably one of the most important threats to the reputational capital of financial firms. Finally, it considers some managerial requisites for dealing with both reputational risk and conflicts of interest.
\end{abstract}

Keywords: Operational Risk, Reputation, Conflicts of Interest, JEL Classification: G2, K2, L14.

\footnotetext{
* Ingo Walter, iwalter@stern.nyu.edu, Stern School of Business, New York University, New York, NY10012, USA, Phone: 001212998070707.
} 
Financial services comprise an array of "special" businesses. They are special because they deal mainly with other people's money, and because problems that arise in financial intermediation can trigger serious external costs. In recent years the role of various types of financial intermediaries has evolved dramatically. Capital markets and institutional asset managers have taken intermediation share from banks. Insurance activities conducted in the capital markets compete with classic reinsurance functions. Fiduciary activities for institutional and retail clients are conducted by banks, broker-dealers, life insurers and independent fund management companies. Intermediaries in each cohort compete as vigorously with their traditional rivals as with players in other cohorts, competition that has been intensified by deregulation and rapid innovation in financial products and processes. Market developments have periodically overtaken regulatory capabilities intended to promote stability and fairness as well as efficiency and innovation.

It is unsurprising that these conditions would give rise to significant reputational risk exposure for the financial firms involved. For their part, investors in banks and other financial intermediaries are sensitive to the going-concern value of the firms they own, and hence to the governance processes that are supposed to work in their interests. Regulators in turn are sensitive to the safety, soundness and integrity of the financial system, and from time to time will recalibrate the rules of the game. Market discipline, operating through the governance process, interacts with the regulatory process in ways that involve both costs and benefits to market participants and are reflected in the value of their business franchises.

Section 1 of this paper defines reputational risk and outlines the sources of reputational risk facing financial services firms. Section 2 considers the key sources of reputational risk in the presence of transactions costs and imperfect information. ${ }^{1}$ Section 3 surveys available empirical research on the impact of

\footnotetext{
${ }^{1}$ Earlier studies focusing on reputation include Chemmanur \& Fulghieri (1994), Smith (1992), Walter \& De Long (1995) and Smith \& Walter (1997).
} 
reputational losses imposed on financial intermediaries, including the separation of reputational losses from accounting losses. Section 4 builds a link between exploitation of conflicts of interest and reputational risk. Section 5 considers managerial requisites for dealing with both reputational risk and conflicts of interest. Section 6 concludes.

\section{What is Reputational Risk?}

Reputational risk in banking and financial services is associated with the possibility of loss in the going-concern value of the financial intermediary - the risk-adjusted value of expected future earnings. Reputational losses may be reflected in reduced operating revenues as clients and trading counterparties shift to competitors, increased compliance and other costs required to deal with the reputational problem - including opportunity costs - an increased firmspecific risk perceived by the market. Reputational risk is often linked to operational risk, although there are important distinctions between the two. According to Basle II, operational risks are associated with people (internal fraud; clients, products and business practices, employment practices and workplace safety), internal processes and systems, and external events (external fraud, damage or loss of assets, and force majeure). Operational risk is specifically not considered to include strategic and business risk, credit risk, market risk or systemic risk, or reputational risk. ${ }^{2}$ If reputational risk is bracketed-out of operational risk from a regulatory perspective, then what is it? A possible working definition is as follows:

Reputational risk comprises the risk of loss in the value of a firm's business franchise that extends beyond event-related accounting losses and is reflected in a decline in its share performance metrics. Reputation-related losses reflect reduced expected revenues and/or higher financing and contracting costs. Reputational risk in turn is related to the strategic positioning and execution of the firm, conflicts of interest exploitation, individual professional conduct, compliance and incentive systems,

\footnotetext{
2 Basle II at http://www.bis.org/publ/bcbs107.htm.
} 
leadership and the prevailing corporate culture. Reputational risk is usually the consequence of management processes rather than discrete events, and therefore requires risk control approaches that differ materially from operational risk.

According to this definition, a reputation-sensitive event might occur which triggers an identifiable monetary decline in the market value of the firm. After subtracting from this market capitalization loss the present value of direct and allocated costs such as fines and penalties and settlements under civil litigation, the balance can be ascribed to the impact on the firm's reputation. Firms that promote themselves as reputational standard-setters will, accordingly, tend to suffer larger reputational losses that firms that have taken a lower profile - that is, reputational losses associated with identical events according to this definition may be highly idiosyncratic to the individual firm.

In terms of the overall hierarchy of risks faced by financial intermediaries, reputational risk is perhaps the most intractable. In terms of Exhibit 1, market risk is usually considered the most tractable, with adequate time-series and crosssectional data availability, appropriate metrics to assess volatility and correlations, and the ability to apply techniques such as value at risk (VaR) and risk-adjusted return on capital (RAROC). Credit risk is arguably less tractable, given that many credits are on the books of financial intermediaries at historical values. The analysis of credit events in a portfolio context falls short of market risk, although many types of credits have over the years become "marketized" through securitization structures such as asset-backed securities (ABS) and collateralized loan obligations (CLOs) as well as derivatives such as credit default swaps (CDS). These are priced in both primary and secondary markets, and transfer some of the granularity and tractability found in market risk to the credit domain. Liquidity risk, on the other hand, has both pluses and minuses in terms of tractability - in continuous markets liquidity risk can be calibrated in terms of bid-offer spreads, although in times of severe market stress and flights to quality liquidity can disappear.

If the top three risk domains in Exhibit 1 show a relatively high degree of 
manageability, the bottom three are less so. Operational risk is a composite of highly manageable risks with a robust basis for suitable risk metrics together with risks that represent catastrophes and extreme values - tail events that are difficult to model and in some cases have never actually been observed. Here management is forced to rely on either simulations or external data to try to assess the probabilities and potential losses. Meanwhile, sovereign risk assessment basically involves applied political economy and relies on imprecise techniques such as stylized facts analysis, so that the track record of even the most sophisticated analytical approaches is not particularly strong - especially under conditions of macro-stress and contagion. As in the case of credit risk, sovereign risk can be calibrated when sovereign foreign-currency bonds and sovereign default swaps (stripped of non-sovereign attributes like external guarantees and collateral) are traded in the market. This leaves reputational risk as perhaps the least tractable of all - with poor data, limited usable metrics, and strong "fat tail" characteristics.

The other point brought out in Exhibit 1 relates to the linkages between the various risk-domains. Even the most straightforward of these - such as between market risk and credit risk - are not easy to model or to value, particularly in a bidirectional form. There are 36 such linkages, exhibiting a broad range of tractability. We would contend that the linkages which relate to reputational risk are among the most difficult to assess and to manage.

\section{Sources of Reputational Risk}

Where does reputational risk in financial intermediation originate? We argue that is emanates in large part from the intersection between the financial firm and the competitive environment, on the one hand, and the direct and indirect network of controls and behavioral expectations within which the firm operates on the other, as depicted generically in Exhibit 2. ${ }^{3}$ The franchise value of a financial institution as a going concern is calibrated against these two sets of benchmarks. 
One of them, market performance, tends to be relatively transparent and easy to reward or punish. The other - performance against corporate conduct benchmarks - is far more opaque but potentially critical as a source of risk to shareholders.

Management must work to optimize against both sets of benchmarks. If it strays too far in the direction meeting the demands of social and regulatory controls, it runs the risk of poor performance in the market, punishment by shareholders, and possibly a change in corporate control. If it strays toward unrestrained market performance and sails too close to the wind in terms of questionable market conduct, its behavior may have disastrous results for the firm, its managers and its shareholders. In the end, striking this balance is a key corporate governance issue.

Such are the rules of the game, and financial intermediaries have to live with them. But they are not immutable. There is constant tension between firms and regulators about appropriate constraints on corporate conduct. Sometimes financial intermediaries win battles (and even wars) leading to periods of deregulation. Sometimes it's possible to convince the public that self-regulation and market discipline are powerful enough to obviate the need for external control. Sometimes the regulators can be convinced, one way or another, to go easy. Then along comes another major transgression and the constraint system reacts and creates a spate of new regulations. A wide array of interests get into this constant battle to define the rules under which financial business gets done - managers, politicians, the media, activists, investors, lawyers, accountants and eventually a new equilibrium gets established which will define the rules of engagement for the period ahead.

There are some more fundamental things at work as well. Laws and regulations governing the market conduct of firms are not created in a vacuum. They are rooted in social expectations as to what is appropriate and inappropriate, which in turn are driven by values imbedded in society. These

\footnotetext{
${ }^{3}$ For an early discussion of external conduct benchmarks, see Galbraith (1973).
} 
values are rather basic. They deal with lying, cheating and stealing, with trust and honor, with what is right and what is wrong. These are the ultimate benchmarks against which conduct is measured and can be the origins of key reputational losses.

But fundamental values in society may or may not be reflected in people's expectations as to how a firm's conduct is assessed. There may be a good deal of slippage between social values and how these are reflected in the public expectations of business conduct. Such expectations are nevertheless important and the build-up of adverse opinion in the media, the formation of special-interest lobbies and pressure-groups, and the general tide of public opinion with respect to one or another aspect of market conduct can be reputationally debilitating.

Moreover, neither values nor expectations are static in time. Both change. But values seem to change much more gradually than expectations. Indeed, fundamental values such as those noted above are probably as close as one comes to "constants" in assessing business conduct. But even in this domain things do change. As society becomes more diverse and mobile, for example, values tend to evolve. They also differ across cultures. And they are sometimes difficult to interpret. Is lying to clients or to trading counterparties wrong? What is the difference between lying and bluffing? Is it only the context that determines how particular behavior is assessed? The same conduct may be interpreted differently under different circumstances - interpretation that may change significantly over time and differ widely across cultures, giving rise to unique contours of reputational risk.

There is additional slippage between society's expectations and the formation of public policy, and the activities of public interest groups. Things may go on as usual for awhile despite occasional media commentary about inappropriate behavior of a firm or an industry in the marketplace. Then some sort of social tolerance limit is reached. A firm goes too far. A confluence emerges among various groups concerned with the issue. The system reacts through the political process and a new set of constraints on firm behavior 
emerge, possibly anchored in legislation, regulation and bureaucracy. Or the firm is subject to class action litigation. ${ }^{4}$ Or its reputation is so seriously compromised that its share price drops sharply.

As managers review the reputational experiences of their competitors, they cannot escape an important message. Most financial firms can endure a credit loss or the cost of an unsuccessful trade or a broken deal, however large, and still survive. These are business risks that the firms have learned to detect and limit their exposure before the damage becomes serious. Reputational losses may be imposed by external reactions that may appear to professionals as unfocused or ambiguous, even unfair. They may also be new - a new reading of the rules, a new finding of culpability, something different from the way things were done before. Although regulators and litigants, analysts and the media are accepted by financial professionals as a fact of life, such outsiders can become susceptible to public uproar and political pressure, during which times it is difficult to take the side of an offending financial firm. ${ }^{5}$

In the United States, for example, tighter regulation and closer surveillance, aggressive prosecution and plaintiff litigation, unsympathetic media and juries, and stricter guidelines for penalties and sentencing make it easier to get into trouble and harder to avoid serious penalties. Global brokerage and trading operations, for example, involve hundreds of different, complex and constantly changing products that are difficult to monitor carefully under the best of circumstances. Doing this in a highly competitive market, where profit margins are under constant challenge and there is considerable temptation to break the rules, is even more challenging. Performance-driven managers, through compensation and promotion practices, have sometimes unwittingly encouraged behavior that has inflicted major reputational damage on their firms and brought some of them down.

The reality is that the value of financial intermediaries suffers from such

\footnotetext{
${ }^{4}$ For a discussion, see Capiello (2006).

${ }^{5}$ For a full examination of these issues, see Smith \& Walter (1997).
} 
uncertain reputation-sensitive conditions. Since maximizing the value of the firm is supposed to be the ultimate role of management, its job to learn how to run the firm so that it optimizes the long-term trade-offs between profits and external control. It does no good to plead unfair treatment - the task is for management to learn to live with it, and to make the most of the variables it can control.

The overall process can be depicted in a graphic such as Exhibit 3 , representing the firm and its internal governance processes in the center and various layers of external controls affecting both the firm's conduct and the reputational consequences of misconduct, ranging from "hard" compliance components near the center to "soft" but potentially vital issues of "appropriate" conduct in the periphery. Clearly, serious reputational losses can impact a financial firm even if it is fully in compliance with regulatory constraints and its actions are entirely legal. The risk of reputational damage incurred in these outer fringes of the web of social control are among the most difficult to assess and to manage. Nor is the constraint system necessarily consistent, with important differences in regulatory regimes (as well as expectations regarding responsible conduct) across markets in which a firm is active - so that conduct which is considered acceptable in one environment may give rise or significant reputational risk in another.

\section{Valuing Reputation Risk}

Recent research has attempted to quantify the impact of reputation risk on share prices during the 1980 s and 1990 s. $^{6}$ Given the nature of the problem, most of the evidence has been anecdotal, although a number of event studies have been undertaken in cases where the reputation-sensitive event was "clean" in terms of the release of the relevant information to the market.

Exhibit 4 summarizes shareholder value losses in a reputation-sensitive situation involving the aforementioned sources of loss - (1) Client defections and revenue erosion; (2) Increases in monetary costs comprising accounting writeoffs 
associated with the event, increased compliance costs, regulatory fines and legal settlements as well as indirect costs related to loss of reputation such as higher financing costs, contracting costs and opportunity costs - including "penalty box" suspension by the regulators from particular business activities; and (3) An increases in firm-specific (unsystematic) risk assigned by the market as a result of the reputational event in question. In order to value the pure reputational losses, it is necessary to estimate the overall market value loss of the firm to a reputation-sensitive event and subtract from it the monetary losses identified in italics in Exhibit 4.

Consider the following example: ${ }^{7}$ On December 28, 1993, the Bank of Spain took control of the country's fourth largest bank, Banco Español de Crédito (Banesto). Subsequently, shares of JP Morgan \& Co., a U.S. bank holding company closely involved with Banesto, declined dramatically. Such a reaction appeared inconsistent with market rationality, given that the impact of the event on Morgan's bottom line was trivial (the accounting loss to Morgan was unlikely to exceed \$10 million after taxes). Perhaps something more than the underlying book value of JP Morgan \& Co. was moving the price of the stock, i.e., the central bank takeover of Banesto may have affected the value of Morgan's corporate franchise in some of the firm's core business areas, notably securities underwriting, funds management, client advisory work and its ability to manage conflicts of interest that can accompany such activities in non-transparent environments.

JP Morgan was involved in Banesto in four ways, in addition to normal interbank transactions relationships: ${ }^{8}$ (1) In May 1992, it began raising funds for the Corsair Partnership, L.P., aimed at making non-controlling investments in financial institutions. By February 1993, Morgan had raised over $\$ 1$ billion from

\footnotetext{
${ }^{6}$ For one of the early studies, see Smith (1992).

${ }^{7}$ Walter and DeLong (1995)

${ }^{8}$ For a journalistic account, see The Wall Street Journal (1994) and Euromoney (1994).
} 
46 investors that included pension funds and private individuals. Morgan served as General Partner and fund manager, with an investment of $\$ 100$ million. The Corsair Partnership's objective was to identify troubled financial institutions and, by improving their performance, earn a significant return to shareholders in the fund. The Corsair Partnership's first investment, undertaken in February 1993, was a share purchase of \$162 million in Banesto - giving Morgan a \$16.2 million equity stake in the Spanish bank. (2) A vice-chairman of JP Morgan served on the Spanish bank's board of directors. (3) Morgan was directly advising Banesto on its financial and business affairs. (4) As part of an effort to recapitalize Banesto, Morgan was lead underwriter during 1993 of two stock offerings that totaled $\$ 710$ million.

Corsair Partnership, L.P. was intended to search for troubled financial institutions in the United States and abroad. The objective was to restructure such institutions by applying Morgan's extensive expertise and contacts. Morgan indicated that Corsair investors could expect a 30\% annual return over ten years. Although Morgan had a separate investment banking subsidiary (JP Morgan Securities Inc.), Corsair was believed to be the first equity fund organized and managed by Morgan since the Glass-Steagall Act separated banking and securities activities in 1933 - a separation which eventually lasted until 1999. The business concept of searching for troubled financial institutions emerged from a time of turmoil in the U.S. and foreign banking sectors. When the U.S. banking industry started to improve as a result of a favorable interest rate environment, Corsair ventured abroad. Corsair's first stake in Banesto was taken in February 1993. By August 1993, it had invested $\$ 162$ million (23\% of the funds raised) in the Spanish bank. The overall J.P. Morgan - Banesto relationship is depicted in Exhibit 5.

Banesto's problems stemmed from rapid growth and a convoluted structure of industrial holdings followed by a serious downturn in the Spanish economy. The bank's lending book increased from Pta.4 trillion in 1988 to Pta2.3 trillion in 1991, a period when its competitors were growing at a quarter of that 
rate. Banesto bid aggressively for deposits, increasing interest rates by $51 \%$ while competitors increased theirs by $40 \%$. When the Spanish economy weakened, the bank was stuck with an array of bad loans and that the group was further burdened by losses on its industrial holdings. In October 1992, a partial audit by the Bank of Spain was forced to lend the troubled institution "a substantial amount". An audit released at the end of December 1993 revealed that Banesto assets of Pta5.5 trillion (\$385 billion) were overvalued in excess of Pta50 billion ( $\$ 3.5$ billion). In April 1994, Banesto was bought for $\$ 2.05$ billion by Banco Santander, leaving costs of $\$ 3.7$ billion to be borne by the Spanish banks and by taxpayers.

Morgan had been advising Banesto on various deals since 1987. In July 1992, Morgan's involvement became more intensive when it began advising Banesto on how to raise capital. By August 1993, Morgan had assisted Banesto in two rights issues to raise $\$ 710$ million. During the time of these rights issues, Corsair invested \$162 million in Banesto. In a letter dated December 27, 1993, Morgan wrote to the Bank of Spain's Governor, outlining how Banesto could continue to raise capital, including a bond issue that Morgan was planning to launch in the first quarter of 1993.

Instead, the Bank of Spain took control of Banesto on the following day, December 28, 1993. Citing mismanagement and reckless lending, the Governor justified the action in order to avoid a run on the deposits of the bank, whose share prices were falling sharply on the Madrid Exchange. Given Morgan's multifaceted involvement in Banesto and potential conflicts imbedded in that relationship, the announcement of the takeover could have had a large effect on the value of Morgan's reputation and business franchise and hence its stock price.

In order to test the impact of the Banesto case on the JP Morgan share price, we use conventional event study methodology. ${ }^{9}$ We create a sample

\footnotetext{
${ }^{9}$ De Long \& Walter (1994). For event study methodology, see Brown and Warner (1985).
} 
prediction of returns on Morgan stock and compare the predicted returns with actual returns on Morgan shares after the Banesto event announcement. The difference is considered the excess return attributable to the event. In order to create this prediction, we regress the daily return of Morgan stock on the daily return on the market index as well as on an industry-group index. ${ }^{10}$ We use data from 300 days to 50 days prior to the announcement date (December 28). The resulting coefficients are then multiplied by the returns on the market and industry indices from 50 days prior to 50 days after the announcement, in order to obtain an estimation of the daily stock return during this period. Then, the excess return is calculated at the "predicted" return minus the actual Morgan stock returns for the period, and the cumulative excess return is plotted. In order to translate these results into the monetary effect on JP Morgan stock, the cumulated excess return is multiplied by the total market value of equity (shares outstanding times price per share) 50 days before the announcement. In effect, this amount represents the difference between what shareholders would have received had they sold their shares in the market 50 days prior to the announcement and the industry's stocks, and what they would have received if they had sold them on subsequent days. If the reputation-effect hypothesis is correct, the market response to the Bank of Spain's announcement on 28 December 1993 should have significantly exceeded the firm's book exposure to Banesto.

We regressed Morgan's stock returns against the value-weighted NYSE index ${ }^{11}$ and the industry group composed of 20 banking and securities firms. We

\footnotetext{
10 The industry group index included 20 financial institutions with characteristics showing some degree of overlap with those of JP Morgan. This is the unweighted average of share prices for Banc One, BankAmerica, Bank of boston, Bank of New York, Bankers Trust NY, Barnett Bank, Bear Stearns, Chase Manhattan, Chemical Bank, Citicorp, Continental Bank, First Chicago, First Fidelity Bancorp, First Virginia, Merrill Lynch, Morgan Stanley Group, NationsBank, Paine Webber Group, Salomon Inc. and Wells Fargo.

${ }^{11}$ While autocorrelation can be a problem in using daily stock returns, JP Morgan stock was heavily traded, so that daily carryover is unlikely to be significant. Indeed, when we controlled the industry for this potential problem by including the lagged market index as a regression, the
} 
obtained the following model, estimated over days -300 to -50 prior to the announcement date:

$R_{J P M t}=-0.00014+0.5766{ }^{\star} R_{M t}+0.2714 * R_{G t}+u_{t}$

where

$\mathrm{R}_{\mathrm{JPMt}}=$ Return on JP Morgan stock;

$\mathrm{R}_{\mathrm{Mt}}=$ Return on NYSE composite (value-weighted) index;

$\mathrm{R}_{\mathrm{Gt}}=$ Return on group of companies in the same industry.

The excess return attributable to the event is the calculated residual $\left(u_{t}\right)$ from 50 days prior to 50 days after the announcement. ${ }^{12}$ Chart 2 shows the cumulative $u_{t}$. Prior to the announcement, Morgan stock behaved as predicted based on its behavior during the 250 days before the event period. A few days before announcement, the return began to decline. Thereafter, an essentially steady decline occurred. A cumulative loss of $10 \%$ of shareholder equity value is apparent 50 days after the announcement. Chart 3 shows this shareholder value loss in monetary terms. It suggests that the $10 \%$ loss in shareholder value translates into a loss in JPM market capitalization of approximately $\$ 1.5$ billion versus a maximum direct loss of only $\$ 10$ million from the Banesto failure. This analysis suggests that the loss of an institution's franchise value can far outweigh an accounting loss when its reputation is called into question, a finding similar to that of Smith (1992) in the case of Salomon Brothers, Inc.

Reasons for the adverse market reaction can only be conjectured. The takeover of Banesto could have been seen as compromising Morgan's reputation in precisely those areas key to its future. Inability to turn Banesto around may have called into question Morgan's ability to successfully advise clients. Banesto as the dominant participation in the Corsair portfolio may have suggested flaws in

resulting coefficient was negative and statistically insignificant.

${ }^{12}$ A careful search was undertaken covering the 50 days after the event to check for further announcements that could have affected the JP Morgan share price. On January 14, 1994, Morgan announced that net earnings for the fourth quarter of 1993 were up by $77 \%$. Despite an increase in earnings, therefore, stock prices fell during the period examined. Besides the statement on earnings, no other announcements occurred during the period. 
Morgan's ability to organize and manage certain equity funds. Underwriting stock and placing them with important investor clients raises questions about its ability to judge risks in underwriting securities. Service on Banesto's Board suggests problems with monitoring and the configuration of Morgan's various involvements with Banesto suggests the potential for conflicts of interest or lack of objectivity. Whatever the linkages, here was a case of a financial services firm of exceedingly high standing, which in no way violated and legal or regulatory constraints but whose shares nevertheless appeared to have been adversely affected by the market reaction to the way a high-profile piece of business was handled.

In recent years, event studies such as this have yielded a growing body of evidence as to the share price sensitivity to reputational risk. For example, Cummins, Lewis and Wei (2006) undertook a large sample study of operational and reputational events contained in the Fitch OpVar ${ }^{\text {TM }}$ database. Exhibit 6 shows the results in terms of the magnitude of the losses using three-factor estimation models in terms of cumulative abnormal returns (CARs) and number of trading days before and after the announcement. The authors, however, do not distinguish between operational losses and reputational losses, as defined above.

De Fontnouvelle et al. (2006) use loss data from the Fitch OpVar ${ }^{\text {Tm }}$ and SAS OpRisk ${ }^{\text {Tm }}$ databases to model operational risk for banks that are internationally active. In a series of robust statistical estimates, they find a high degree of regularity in operational losses that are both quantifiable and consistent with large amount of capital increasingly reported by major banks as being held against operational risk - which in many cases exceeds capital held against market risk - see Exhibits 7 and 8 . The paper also segments the losses by event type and by activity line, as well as whether or not the operational losses occurred in the United States. The largest losses involved retail and commercial and retail/private banking activities in terms of type of event. As in the case of other studies, the authors do not distinguish the associated 
accounting losses due to legal settlements, fines, penalties and other explicit operational risk-related costs from reputational losses, and as such these estimates are relevant from a regulatory perspective but probably materially understate the losses to shareholders.

In a pilot study of 49 reputation-sensitive events, using the aforementioned definition and excluding operational events, we find negative mean CARs of up to $7 \%$ and $\$ 3.5$ billion, depending on the event windows used. Exhibit 9 shows the results graphically and the tables in Exhibits 10 and 11 show the numerical results. We do not, however, distinguish between the associated monetary losses and the pure reputational losses. ${ }^{13}$

The only study so far which attempts to identify pure reputational losses is Karpoff, Lee and Martin (2006). The authors attempt to distinguish book losses from reputational losses in the context of US Securities and Exchange Commission enforcement actions related to earnings restatements - "cooking the books." The authors review 2,532 regulatory events in connection with all relevant SEC enforcement actions during 1978-2002 and the monetary costs of these actions in the ensuing period, through 2005 . These monetary costs are then compared with the cumulative abnormal returns estimated from event studies to separate them from the reputational costs. The results are depicted in Exhibit 12 - note that the reputational losses (66\%) are far larger than the cost of fines (3\%), class action settlements (6\%) and accounting writeoffs (25\%) resulting from the events in question.

\section{Reputational Risk and Conflicts of interest}

One of the key sources of reputational risk in the financial services sector is the exploitation of conflicts of interest. Potential conflicts of interest are a fact of life in the financial services industry, and always will be. The question is whether they are exploited, and thereby impose agency costs on others. In

\footnotetext{
${ }^{13}$ Ongoing empirical work on reputation-sensitive financial services events with Gayle De Long and Anthony Saunders.
} 
recent years, the role of banks, securities firms, insurance companies and asset managers have become enmeshed in alleged abusive practices - as facilitators in various corporate scandals, acting simultaneously as principals and intermediaries in various high-profile transactions, for example. This has turned the attention of supervisory authorities, public prosecutors, legislators and the conflict of interest issue. ${ }^{14}$

In this section we note that conflict-of-interest exploitation requires information asymmetries, transaction costs and market frictions - in perfect markets, conflicts of interest cannot be exploited. We argue that conflict of interest exploitation is sensitive to the strategic positioning of the financial intermediary, as well as strategic execution and the intensity of performance pressure imposed on individual business units. Finally, we suggest that appropriate conflict of interest diagnostics can promote sensible safeguards against the reputational exposure involved.

There are essentially two kinds of conflicts of interest confronting firms in the financial services industry: (Type-1) Conflicts between the firm's own economic interests and the interests of its clients. Examples include exploiting conflicts of interest in order to enhance the firm's profitability or market-share, or to transfer risk. (Type-2) Conflicts of interest may develop between the firm's clients (or between types of clients) which place the firm in a position of favoring one at the expense of another. Behavior that systematically favors corporate clients over retail investors in the presence of asymmetric information is an example of this type of conflict. (Walter, 2004)

Each of these types of conflicts of interest may arise either in interprofessional activities carried out in wholesale financial markets or in activities involving retail clients. The distinction between these two domains is important because of the key role of information asymmetries and transactions costs, which differ dramatically between the two broad types of market participants.

\footnotetext{
${ }^{14}$ A survey of the economics of conflicts of interest can be found in Demsky (2003). Analysis of conflicts of interest applied to the financial services industry includes Herman (1975), Krozner \&
} 
Consequently, their vulnerability to conflict-exploitation differs significantly, and measures designed to remedy the problem in one domain may be inappropriate in the other. In addition there are what we term "domain-transition" conflicts of interest, which run between the two domains and whose impact can be particularly troublesome.

Conflicts of interest in wholesale financial markets are depicted in Exhibit 13. For example, a financial intermediary may be involved as a principal with an equity stake in a transaction in which it is also serving as adviser, lender or underwriter, creating an incentive to act in its own interest and against those of its clients or third parties. Or a financial intermediary may use its lending power to influence a client to use its securities or advisory services as well - or the reverse, denying credit to clients that refuse to use other (more profitable) services. Or the asset management unit of a financial institution may be pressured by a corporate banking client into proxy-voting of shares in that company for management's position in a contested corporate action. Or a multifunctional financial firm may act as trading counterparty for its own fiduciary clients, as when the firm's asset management unit sells or buys securities for a fiduciary client while its affiliated broker-dealer is on the other side of the trade. Or a financial intermediary may exploit institutional, corporate or other wholesale clients by executing proprietary trades in advance of client trades that may move the market.

All of these represent exploitation of Type-1 conflicts, which set the firm's own interest against those of its clients in wholesale, interprofessional transactions. Type-2 conflicts dealing with differences in the interests of multiple wholesale clients center predominantly on two issues: (1) A financial intermediary may obtain private information about a client, which in turn may be used in ways that harm the interests of that client; or (2) A financial firm may have a relationship with two or more clients who are themselves in conflict.

Conflicts of interest in retail financial markets are depicted in Exhibit 14.

Strahan (1999), Saunders (1985) and Schotland (1980). 
All such conflicts appear to be Type 1 conflicts, which set the interests of the financial intermediary itself against the interests of its clients. They include biased client advice based on a "salesman's stake" in promoting high-margin "house" products over lower-margin third-party products, based on incentives that are rarely transparent to the retail client. Or retail clients may be pressured to acquire additional financial services on unfavorable terms in order to access a particular product, such as the purchase of credit insurance tied to consumer or mortgage loans. Or a financial firm that is managing assets for clients may exploit its agency relationship by engaging in excessive trading which creates higher costs. Or clients may be encouraged to leverage their investment positions through margin loans from the firm, exposing them to potentially unsuitable levels of market risk and high credit costs. Or there may be misuse of personal information by a firm under intense pressure to cross-sell.

Conflicts of interest exploitation may also transition the wholesale and retail domains, as depicted in Exhibit 15 This can involve either Type-1 or Type-2 conflicts, and sometimes both at the same time. One example is the classic conflict between a firm's "promotional role" in raising capital for clients in the financial markets and its obligation to provide suitable investments for retail clients. ${ }^{15}$ Or a financial firm that is acting as an underwriter or has or acquired securities in a secondary market trade may be unable to resell them at an acceptable price and may seek to cut its exposure to loss by allocating unwanted securities to investment accounts over which it has discretion. Or analysts working for sell-side firms in diverse and fundamentally incompatible roles may encounter intractable conflicts in taking views on listed equities. Or a bank with credit exposure to a client whose bankruptcy risk has increased (to the private knowledge of the banker) may have an incentive to assist the corporation in issuing bonds or equities to the general public, with the proceeds used to pay-

\footnotetext{
${ }^{15}$ A well-known version of this conflict involves biased research. See Attorney General of the state of New York (2003).
} 
down the bank's loans.

Aside from this basic taxonomy of conflict of interest exploitation, we posit that the broader the range of a financial intermediary's activities, (1) the greater the likelihood that the firm will encounter exploitable conflicts of interest, (2) the higher will be the potential agency costs facing its clients, and (3) the more difficult and costly will be the safeguards necessary to prevent conflict of interest exploitation. If this proposition is correct, agency costs associated with conflicts of interest can easily offset the realization of economies of scope in financial services firms - scope economies that are supposed to generate benefits on the demand side through cross-selling (revenue synergies) and on the supply side through more efficient use of the firm's business infrastructure (cost synergies). As a result of conflict exploitation the firm may win and clients may lose in the first instance, but subsequent adverse reputational and regulatory consequences (along with efficiency factors such as the managerial and operational cost of complexity) can be considered diseconomies of scope.

Breadth of engagement with clients may create conflicts of interest that can be multidimensional, and involve a number of different stakeholders at the same time. Several examples came to light during the corporate scandals in the early 2000s. Following the $\$ 103$ billion bankruptcy of WordCom in 2002, for example, it appeared that Citigroup - a multifunctional, global financial conglomerate - was serving as equity analyst supplying assessments of WorldCom to institutional and (through the firm's brokers) retail clients, while simultaneously advising WorldCom management on strategic and financial matters. Citigroup's equity analyst at times participated in WorldCom's board meetings. As a major telecommunications-sector commercial and investment banking client, Citigroup maintained an active lending relationship with WorldCom and successfully competed for its securities underwriting business. At the same time, Citigroup served as the exclusive pension fund adviser to WorldCom and executed significant stock option trades for WorldCom 
executives, while at the same time conducting proprietary trading in WorldCom stock and holding a significant position in the company's stock through its asset management unit. Additionally, Citigroup advised the WorldCom CEO, financed margin purchases of company stock, and provided loans for one of his private businesses.

On the one hand, Citigroup was very successfully engaged in the pursuit of revenue economies of scope (cross-selling), simultaneously targeting both the asset and liability sides of its client's balance sheet, generating advisory fee income, managing assets, and meeting the private banking needs of WorldCom's CEO. On the other hand, that same success caught the firm in simultaneous conflicts of interest relating to retail investors, institutional fund managers, WorldCom executives and shareholders as well as Citigroup's own positions in WorldCom credit exposure and stock trades. WorldCom's bankruptcy triggered a large market capitalization loss for Citigroup's own shareholders, only part of which can be explained by a $\$ 2.65$ billion civil settlement the firm reached with investors in May 2004. ${ }^{16}$

It seems plausible that the broader the range of services that a financial firm provides to a given client in the market, and the greater the cross-selling pressure, the greater the potential likelihood that conflicts of interest will be compounded in any given case and, when these conflicts of interest are exploited, the more likely they are to damage the market value of the financial firm's business franchise once they come to light. Similarly, the more active a financial intermediary becomes in principal transactions such as affiliated private equity businesses and hedge funds, the more exposed it is likely to be to reputational risk related to conflicts of interest.

\footnotetext{
${ }^{16}$ Similar issues surfaced in the case of the 2001 Enron bankruptcy. See Batson (2003) and Healy \& Palepu (2003).
} 


\section{Controlling Conflicts of Interest}

Mechanisms to control conflicts of interest are based on either regulation, civil litigation or market discipline - often a combination. These external controls, in turn, form the basis for a set of internal controls, which can be either prohibitive or affirmative, involving in the first instance the behavioral "tone" and incentives set by boards and senior management together with reliance on the loyalty and professional conduct of employees. They are fundamentally matters of sound corporate governance.

Regulatory control of conflicts of interest tends to be applied through both SROs and public agencies, and is generally anchored in banking, insurance, securities and consumer protection legislation that is supposed to govern market practices. Its failure to prevent serious exploitation of conflicts of interest became evident in the US and elsewhere during the early 2000s with serial revelations of misconduct by financial intermediaries. The corrective initiative in this instance was taken not by the responsible SROs (the NYSE or the NASD, for example) or by the national regulators (such as the SEC), but in large measure by the New York State Attorney General under the Martin Act, a 1921 state law aimed at securities fraud which survived all subsequent banking and securities legislation and was bolstered in 1955 with the addition of criminal penalties. The Act contains extremely broad "fraud" provisions and conveys unusually wide discovery and subpoena power, but had been largely dormant until the 2001-02 revelations of the excesses in financial market practices and corporate governance. The de facto ceding of enforcement actions by the SROs and the SEC to a state prosecutor (later joined by several others) focused attention on gaps in regulation and led to a burst of activity by the SROs, the regulators and the Congress, including the 2002 Sarbanes-Oxley Act. It also led to a large number nolo contendere settlements by major banks and securities firms, none of which created any useful legal guidance for the future.

Civil litigation proved to be an important component of external control of 
financial intermediary conduct, especially when linked to regulatory sanctions. Despite high costs and occasional unjust outcomes, US tort litigation is arguably an important adjunct to market discipline with respect to exploitation of conflicts of interest. Nevertheless, both regulatory action and civil litigation are blunt instruments in dealing with exploitation of conflicts of interest in financial intermediaries, conflicts that are often extremely granular and sometimes involve conduct that is "inappropriate" or "unethical" rather than "illegal" in terms of Exhibit 3. So market discipline via reputational impacts on share prices may provide a more consistent and durable basis for Internal defenses against exploitation of conflicts of interest than those mandated by the regulators or implemented through the compliance infrastructure by legal staff reporting to senior management - or the threat of litigation. There are several linkages that can be identified.

First, market discipline can leverage the effectiveness of regulatory actions. When they are announced, regulatory actions can have an adverse effect on a financial firm's share price and competitive advantage linked to the share price such as the cost of capital, the ability to make acquisitions and vulnerability to takeover, and management compensation. As noted, any such share-price effects reflect the market's response to the prospective combined impact of regulatory actions on revenues, costs and exposure to risk. In addition, regulatory actions or abrupt share price declines can trigger derivative civil litigation. In extreme cases the firm could be taken over, broken up of go out of business. Awareness of these risks on the part of boards and managements ought to be reflected in compensation arrangements as well as organizational structure - effective separation in wholesale financial intermediation of trading, asset management and corporate finance, for example.

Second, even in the absence of regulatory constraints - actions that are widely considered to be "unfair," "unethical" or otherwise contrary to the external constraint system discussed earlier - will tend to be subject to market discipline 
through its reputational impacts. In a competitive context, this will affect firm valuation through the revenue and risk dimensions identified in Exhibit 4, in particular. That is, even in the absence of regulatory constraints, management ought to be aware that efforts to avoid conflict of interest exploitation and other sources of reputational damage is likely to reinforce the value of the firm as a going concern and, with properly structured incentives, their own rewards. Since they tend to be more granular and applied in a real-time context, market discipline constraints can reach the more opaque risks to reputational capital, including conflict of interest exploitation. It can identify such issues as they occur in real time, which external regulation normally cannot do.

Third, since market-conduct regulation tends to be linked to be information asymmetries and transactions costs, optimum regulation should be carefully tailored to market domain - notably the wholesale and retail domains. Often this is not possible, resulting in overregulation in some areas and underregulation in others. Market discipline-based constraints can help alleviate this problem by permitting lower overall levels of regulation. Particularly in the case of conflicts of interest that bridge the wholesale and retail domains, market discipline can be effective in dealing with faultlines across financial market segments. And, just as market discipline can reinforce the effectiveness of regulation, it can also can serve as a precursor of sensible regulatory change.

Fourth, market structure and competition across strategic groups can help determine the effectiveness of market discipline. For example, inside information accessible to a bank as lender to a target firm would almost certainly preclude its affiliated investment banking unit from acting as an adviser to a potential acquirer. An entrepreneur may not want his or her private banking affairs handled by a bank that also controls his or her business financing. A broker may be encouraged by a firm's compensation arrangements to sell in-house mutual funds or externally-managed funds with high fees under "revenue-sharing" arrangements, as opposed to funds that would better suit the client's needs. Market discipline that helps avoid exploitation of such conflicts of interest may be limited if most of the competition is coming from financial 
conglomerates that face the same issues. But if the playing field is also populated by aggressive insurance companies, broker-dealers, fund managers and other "monoline" specialists, market discipline may be much more effective.

\section{Conclusions}

We have attempted to define reputational risk and to outline the sources of such risk facing financial services firms. It then considered the key drivers of reputational risk in the presence of transactions costs and imperfect information and surveyed available empirical research on the impact of reputational losses imposed on financial intermediaries. We then developed the link between reputational risk and exploitation of conflicts of interest, arguably one of the most important threats to the reputational capital of a financial intermediary. Finally, we considered managerial requisites for dealing with both reputational risk and conflicts of interest.

We conclude that market discipline, through the reputation-effects on the franchise value of financial intermediaries, can be a powerful complement to regulation and civil litigation. Nevertheless, market discipline-based controls remain controversial. Financial firms continue to encounter serious instances of reputation loss due to misconduct despite its effects on the value of their franchises. This suggests material lapses in the governance process.

Dealing with reputational risk and controlling exploitation of conflicts of interest can be an expensive business, with compliance systems that are costly to maintain and various types of walls between business units and functions that impose significant opportunity costs due to inefficient use of information within the organization. Moreover, management of certain kinds of conflicts in multifunctional financial firms may be sufficiently difficult to require structural remediation. On the other hand, reputation losses associated with conflict of interest exploitation can cause serious damage - as demonstrated by reputation-sensitive "accidents" that seem to occur repeatedly in the financial services industry. Indeed, it can be argued that such issues contribute to market valuations among financial conglomerates that fall below valuations of more 
specialized financial services businesses. (Laeven \& Levine, 2005; Schmid \& Walter, 2006). ${ }^{17}$

Managements and boards of financial intermediaries must be convinced that a good defense is as important as a good offense in determining sustainable competitive performance. This is something that is extraordinarily difficult to put into practice in a highly competitive environment for both financial services and for the highly skilled professionals that comprise the industry. It seems to require an unusual degree of senior management leadership and commitment. (Smith \& Walter, 1997) Internally, there have to be mechanisms that reinforce the loyalty and professional conduct of employees. Externally, there has to be careful and sustained attention to reputation and competition as disciplinary mechanisms. In the end, it is probably leadership more than anything else that separates winners from losers over the long term - the notion that appropriate professional behavior reinforced by a sense of belonging to a quality franchise constitutes a decisive comparative advantage.

\section{References}

Attorney General of the State of New York. (2003) Global Settlement: Findings of Fact (Albany: Office of the State Attorney General).

Batson, Neal. (2003) Final Report, Chapter 11, Case No. 01-16034 (AJG), United States Bankruptcy Court, Southern District of New York, July 28.

Brown, Stephen J. and Jerold B. Warner (1985). "Using Daily Stock Returns: The Case of Event Studies." Journal of Financial Economics, 14, 3-31.

Capiello, S. (2006) "Public Enforcement and Class Actions Against Conflicts of Interest in Universal Banking - The US Experience Vis-à-vis Recent Italian Initiatives." Bank of Italy, Law and Economics Research Department, Working Paper.

Chemmanur, Thomas J. and Paolo Fulghieri. (1994) "Investment Bank Reputation, Information Production, and Financial Intermediation," Journal of Finance, 49, March.

De Fontnouvelle, Patrick, Virginia DeJesus-Rueff, John S. Jordan and Eric S. Rosengren (2006). "Capital and Risk: New Evidence on Implications of Large

${ }^{17}$ See also Kanatas \& Qi (2003) and Saunders \& Walter (1997). 
Operational Losses." Federal Reserve Bank of Boston. Working Paper. September.

De Long, Gayle and Ingo Walter. (1994) "J.P. Morgan and Banesto: An Event Study." New York University Salomon Center. Working Paper. April.

Demsky, Joel S. (2003) "Corporate Conflicts of Interest," Journal of Economic Perspectives, Vol. 17., No. 2, Spring.

Galbraith, John Kenneth. (1973) Economics and the Public Purpose (New York: Macmillan).

Herman. Edward S. (1975) Conflicts of Interest: Commercial Banks and Trust Companies (New York: Twentieth Century Fund).

Healey, Paul M. and Krishna G. Palepu. (2003) "The Fall of Enron," Journal of Economic Perspectives, Vol. 17., No. 2, Spring.

Kanatas, George, and Jianping Qi. (2003) "Integration of Lending and Underwriting: Implications of Scope Economies," Journal of Finance, 58 (3).

Krozner, Randall S. And Philip E. Strahan. (1999) "Bankers on Boards, Conflicts of Interest, and Lender Liability," NBER Working Paper No. W7319, August.

Laeven, Luc and Ross Levine. (2005). "Is There a Diversification Discount in Financial Conglomerates?" C.E.P.R. Discussion Papers No. 5121.

Saunders, Anthony. (1985) "Conflicts of Interest: An Economic View," in Ingo Walter (ed.) Deregulating Wall Street (New York: John Wiley).

Saunders, Anthony and Ingo Walter. (1997) Universal Banking In the United States: What Could We Gain? What Could We Lose? (New York: Oxford University Press).

Schmid, Markus M. and Ingo Walter. (2006) "Do Financial Conglomerates Create or Destroy Economic Value?" SSRN: http://ssrn.com/abstract=929160.

Schotland, R.A. (1980) Abuse on Wall Street: Conflicts of Interest in the Securities Markets (Westport, Ct.: Quantum Books).

Smith, Clifford W. (1992) "Economics and Ethics: The Case of Salomon Brothers" Journal of Applied Corporate Finance, Vol. 5, No. 2, Summer.

Smith, Roy C. and Ingo Walter. (1997) Street Smarts: Linking Professional Conduct and Shareholder Value in the Securities Industry (Boston: Harvard Business School Press). 
Walter, Ingo. (2004) "Conflicts of Interest and Market Discipline in Financial Services Firms." In Claudio Borio, William Curt Hunter, George G. Kaufman, and Kostas Tsatsaronis, Market Discipline Across Countries and Industries (Cambridge: MIT Press).

Walter, Ingo and Gayle DeLong, "The Reputation Effect of International Merchant Banking Accidents: Evidence from Stock Market Data," New York University Salomon Center, Working Paper, 1995). 
Exhibit 1

A Hierarchy of Risks Confronting Financial Intermediaries

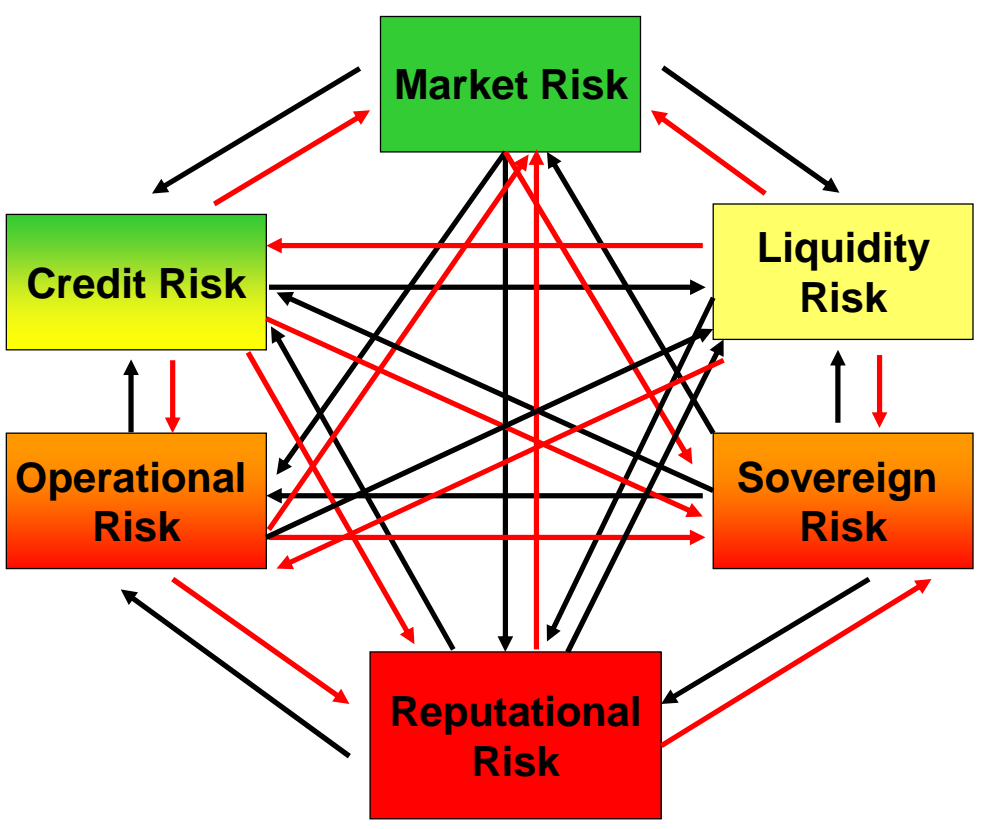

Exhibit 2

Reputational Risk and External Control Web

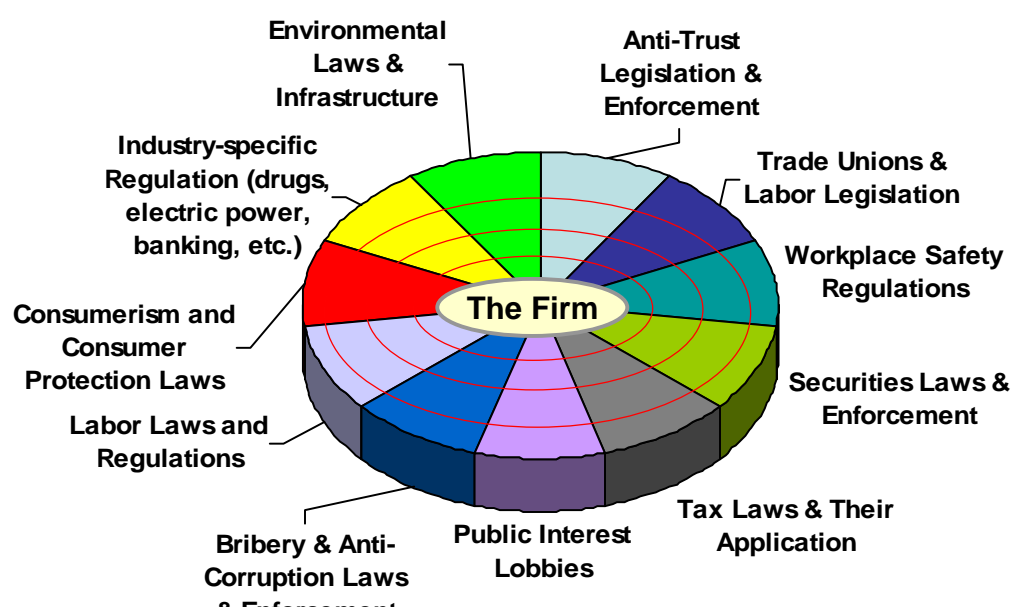

\& Enforcement 
Exhibit 3

Performance Gaps, Competition and Conflict

SOCIETY'S GENERALLY ACCEPTED VALUES

"Immoral Conduct"

PEOPLE'S EXPECTATIONS

"Irresponsible Conduct"

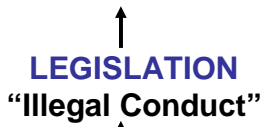

"Illegal Conduct"

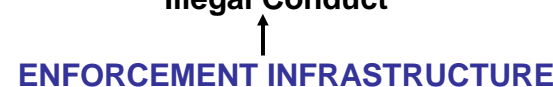

"External Compliance Failure"

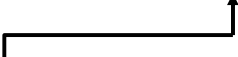

Reputational Benchmarks

$\rightarrow$ MARKET-BASED COMPETITIVE PERFORMANCE

Exhibit 4

Reputational-sensitive Events in a Simple Going-concern Valuation Framework

$$
N_{t} \begin{aligned}
& \text { Client defections } \\
& \text { \& revenue erosion }
\end{aligned}
$$


Exhibit 5

Reputational Risk Exposure - JP Morgan and Banco Español de Crédito, 1993

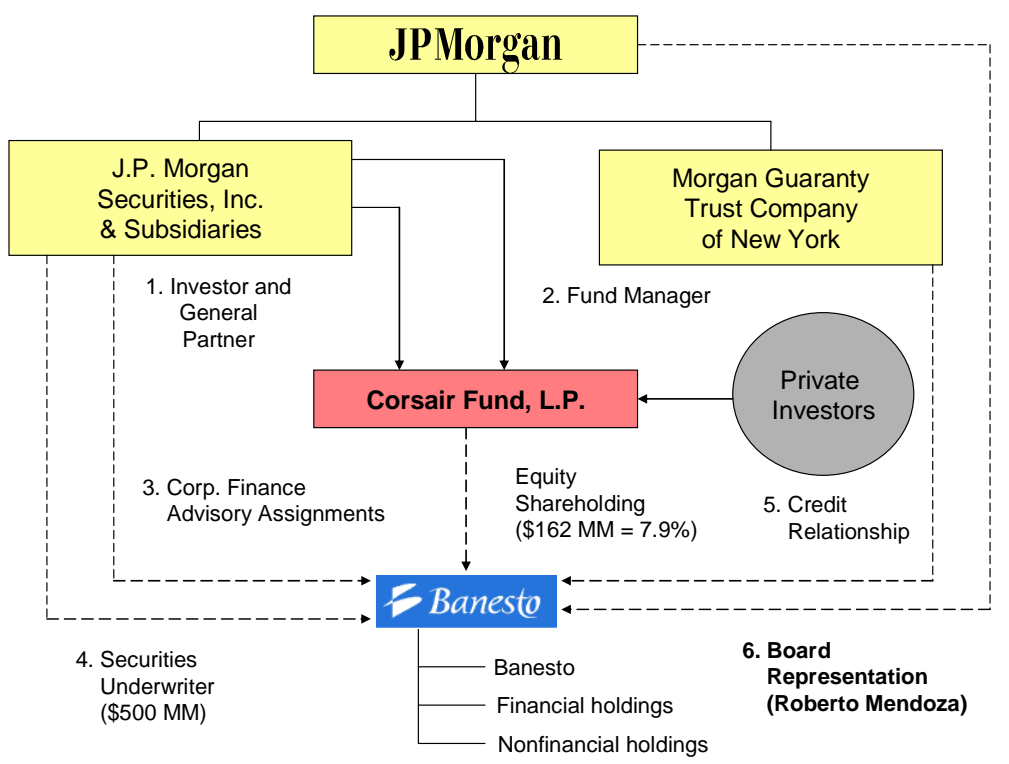

Exhibit 6

Cumulative Abnormal Returns (CARs) for Banks and Insurers In a Large-Sample Study of Operational and Reputational Evente (three-factor models)

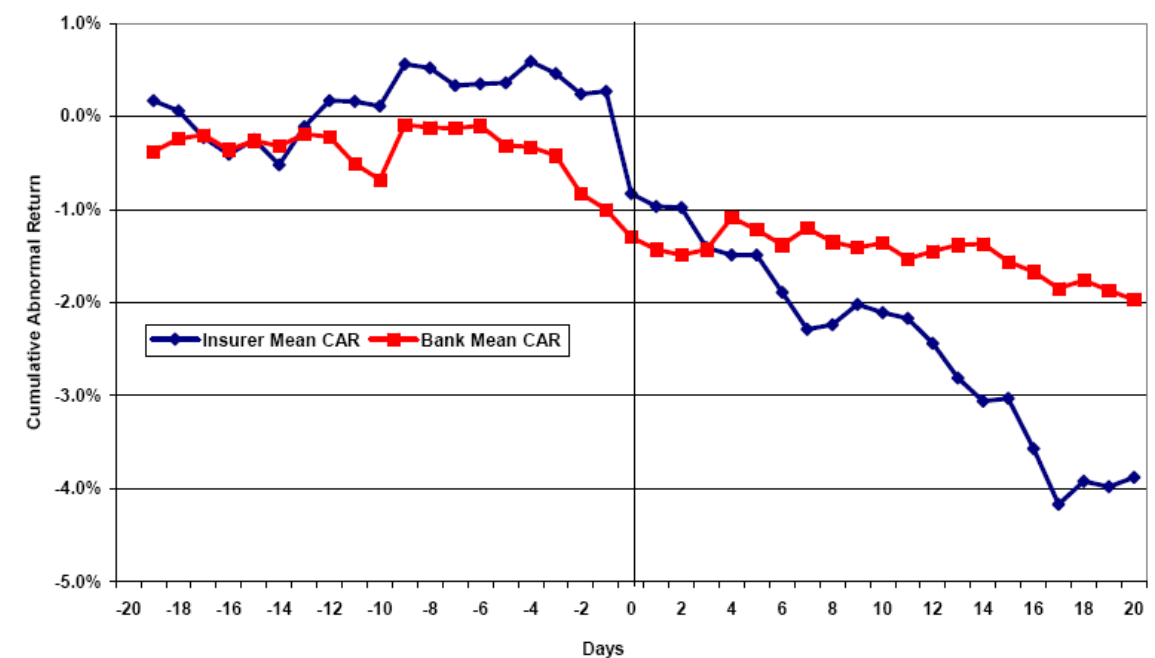

J. David Cummins, Christopher M. Lewis and Ran Wei, "The Market Impact of Operational Risk Events for US Banks and Insurers," Journal of Banking and Finance, . Volume 30, Issue 10, October 2006, Pages 2605-2634. 
Exhibit 7 - Operational Losses by Event Type

\begin{tabular}{|c|c|c|c|c|c|c|c|c|c|}
\hline \multirow[b]{3}{*}{ Event Type } & \multicolumn{4}{|c|}{ SAS OpRisk } & \multicolumn{4}{|c|}{ Fitch OpVar } & \multirow{3}{*}{$\begin{array}{r}\text { Wilcoxon } \\
\text { Test }\end{array}$} \\
\hline & \multirow{2}{*}{$\begin{array}{c}\% \text { of All } \\
\text { Losses }^{\mathrm{a}}\end{array}$} & \multicolumn{3}{|c|}{ Percentiles (\$M) } & \multirow{2}{*}{$\begin{array}{l}\% \text { of All } \\
\text { Losses }^{\mathrm{a}}\end{array}$} & \multicolumn{3}{|c|}{ Percentiles (\$M) } & \\
\hline & & $50 \%$ & $75 \%$ & $95 \%$ & & $50 \%$ & $75 \%$ & $95 \%$ & \\
\hline All Event Types & $100.0 \%$ & 6 & 17 & 88 & $100.0 \%$ & 6 & 17 & 93 & $90.2 \%$ \\
\hline Internal Fraud & $23.0 \%$ & 4 & 10 & 42 & $27.0 \%$ & 6 & 16 & 110 & $1.2 \%$ \\
\hline External Fraud & $16.5 \%$ & 5 & 17 & 93 & $16.6 \%$ & 4 & 12 & 70 & $33.2 \%$ \\
\hline EPWS & $3.0 \%$ & 4 & 14 & - & $3.3 \%$ & 5 & 11 & - & $95.0 \%$ \\
\hline CPBP & $55.5 \%$ & 7 & 20 & 95 & $48.1 \%$ & 7 & 20 & 99 & $96.3 \%$ \\
\hline Damage Phys. Assets & $0.4 \%$ & 18 & - & - & $0.3 \%$ & 20 & - & - & $92.9 \%$ \\
\hline BDSF & $0.2 \%$ & 36 & - & - & $0.4 \%$ & 10 & - & - & $38.0 \%$ \\
\hline EDPM & $1.3 \%$ & 9 & 27 & - & $4.2 \%$ & 4 & 11 & - & $14.6 \%$ \\
\hline
\end{tabular}

Panel B. Losses that occurred outside the U.S.

\begin{tabular}{lrrrrrrrrr} 
All Event Types & $100.0 \%$ & 10 & 36 & 221 & $100.0 \%$ & 13 & 46 & 288 & $16.7 \%$ \\
Internal Fraud & $48.5 \%$ & 9 & 35 & 259 & $42.9 \%$ & 15 & 62 & 381 & $1.5 \%$ \\
External Fraud & $15.3 \%$ & 7 & 27 & - & $21.6 \%$ & 10 & 28 & 136 & $27.3 \%$ \\
EPWS & $0.8 \%$ & 7 & - & - & $1.6 \%$ & 2 & 7 & - & $75.3 \%$ \\
CPBP & $32.6 \%$ & 14 & 51 & 374 & $28.6 \%$ & 13 & 51 & 359 & $99.6 \%$ \\
Damage Phys. Assets & $0.0 \%$ & - & - & - & $0.3 \%$ & 163 & - & - & - \\
BDSF & $0.8 \%$ & 7 & - & - & $0.5 \%$ & 3 & - & - & $42.3 \%$ \\
EDPM & $1.9 \%$ & 29 & - & - & $4.6 \%$ & 5 & 19 & - & $8.1 \%$ \\
\hline Kruskal-Wallis Test & $11.8 \%$ & & & & $5.5 \mathrm{E}-05$ & & & &
\end{tabular}

Source: De Fontnouvelle, Patrick, Virginia DeJesus-Rueff, John S. Jordan and Eric S. Rosengren (2006). Capital and Risk: New Evidence on Implications of Large Operational Losses." Federal Reserve Bank of Boston. Working Paper. September.

Exhibit 8 - Operational Losses by Business Line

\begin{tabular}{|c|c|c|c|c|c|c|c|c|c|}
\hline \multirow[b]{3}{*}{ Business Line } & \multicolumn{4}{|c|}{ SAS OpRisk } & \multicolumn{4}{|c|}{ Fitch OpVar } & \multirow{3}{*}{$\begin{array}{r}\text { Wilcoxon } \\
\text { Test }\end{array}$} \\
\hline & \multirow{2}{*}{$\begin{array}{l}\% \text { of All } \\
\text { Losses }^{\mathrm{a}}\end{array}$} & \multicolumn{3}{|c|}{ Percentiles (\$M) } & \multirow{2}{*}{$\begin{array}{c}\% \text { of All } \\
\text { Losses }^{\mathrm{a}}\end{array}$} & \multicolumn{3}{|c|}{ Percentiles $(\$ M)$} & \\
\hline & & $50 \%$ & $75 \%$ & $95 \%$ & & $50 \%$ & $75 \%$ & $95 \%$ & \\
\hline All Business Lines & $100 \%$ & 6 & 17 & 88 & $100 \%$ & 6 & 17 & 93 & $90.2 \%$ \\
\hline Corporate Finance & $6 \%$ & 6 & 23 & - & $4 \%$ & 8 & 23 & - & $55.8 \%$ \\
\hline Trading \& Sales & $9 \%$ & 10 & 44 & 334 & $9 \%$ & 10 & 27 & 265 & $89.2 \%$ \\
\hline Retail Banking & $38 \%$ & 5 & 11 & 52 & $39 \%$ & 5 & 12 & 60 & $73.1 \%$ \\
\hline Commercial Banking & $21 \%$ & 7 & 24 & 104 & $16 \%$ & 8 & 28 & 123 & $13.3 \%$ \\
\hline Payment \& Settlement & $1 \%$ & 4 & 11 & - & $1 \%$ & 4 & 11 & - & $65.8 \%$ \\
\hline Agency Services & $2 \%$ & 22 & 110 & - & $3 \%$ & 9 & 28 & - & $10.3 \%$ \\
\hline Asset Management & $5 \%$ & 8 & 20 & - & $6 \%$ & 8 & 22 & 165 & $80.8 \%$ \\
\hline Retail Brokerage & $17 \%$ & 4 & 12 & 57 & $22 \%$ & 4 & 13 & 67 & $98.0 \%$ \\
\hline Kruskal-Wallis Test & 2.9E-07 & & & & $1.0 \mathrm{E}-12$ & & & & \\
\hline
\end{tabular}

Panel B. Losses that occurred outside the U.S.

\begin{tabular}{lrrrrrrrrr} 
All Business Lines & $100 \%$ & 10 & 36 & 221 & $100 \%$ & 13 & 46 & 288 & $16.7 \%$ \\
Corporate Finance & $2 \%$ & 13 & - & - & $3 \%$ & 12 & 27 & - & $69.3 \%$ \\
Trading \& Sales & $9 \%$ & 30 & 125 & - & $12 \%$ & 25 & 66 & - & $35.3 \%$ \\
Retail Banking & $41 \%$ & 6 & 27 & 101 & $44 \%$ & 9 & 29 & 272 & $10.4 \%$ \\
Commercial Banking & $30 \%$ & 15 & 42 & 437 & $21 \%$ & 35 & 91 & 323 & $2.4 \%$ \\
Payment \& Settlement & $1 \%$ & 5 & - & - & $1 \%$ & 13 & - & - & $17.7 \%$ \\
Agency Services & $2 \%$ & 45 & - & - & $3 \%$ & 20 & 77 & - & $49.6 \%$ \\
Asset Management & $3 \%$ & 5 & 47 & - & $5 \%$ & 7 & 23 & - & $90.1 \%$ \\
Retail Brokerage & $12 \%$ & 10 & 42 & - & $11 \%$ & 8 & 34 & - & $42.6 \%$ \\
\hline Kruskal-Wallis Test & $6.6 \mathrm{E}-04$ & & & & $1.1 \mathrm{E}-05$ & & & &
\end{tabular}

Source: De Fontnouvelle, Patrick, Virginia DeJesus-Rueff, John S. Jordan and Eric S. Rosengren (2006). Capital and Risk: New Evidence on Implications of Large Operational Losses." Federal Reserve Bank of Boston. Working Paper. September. 


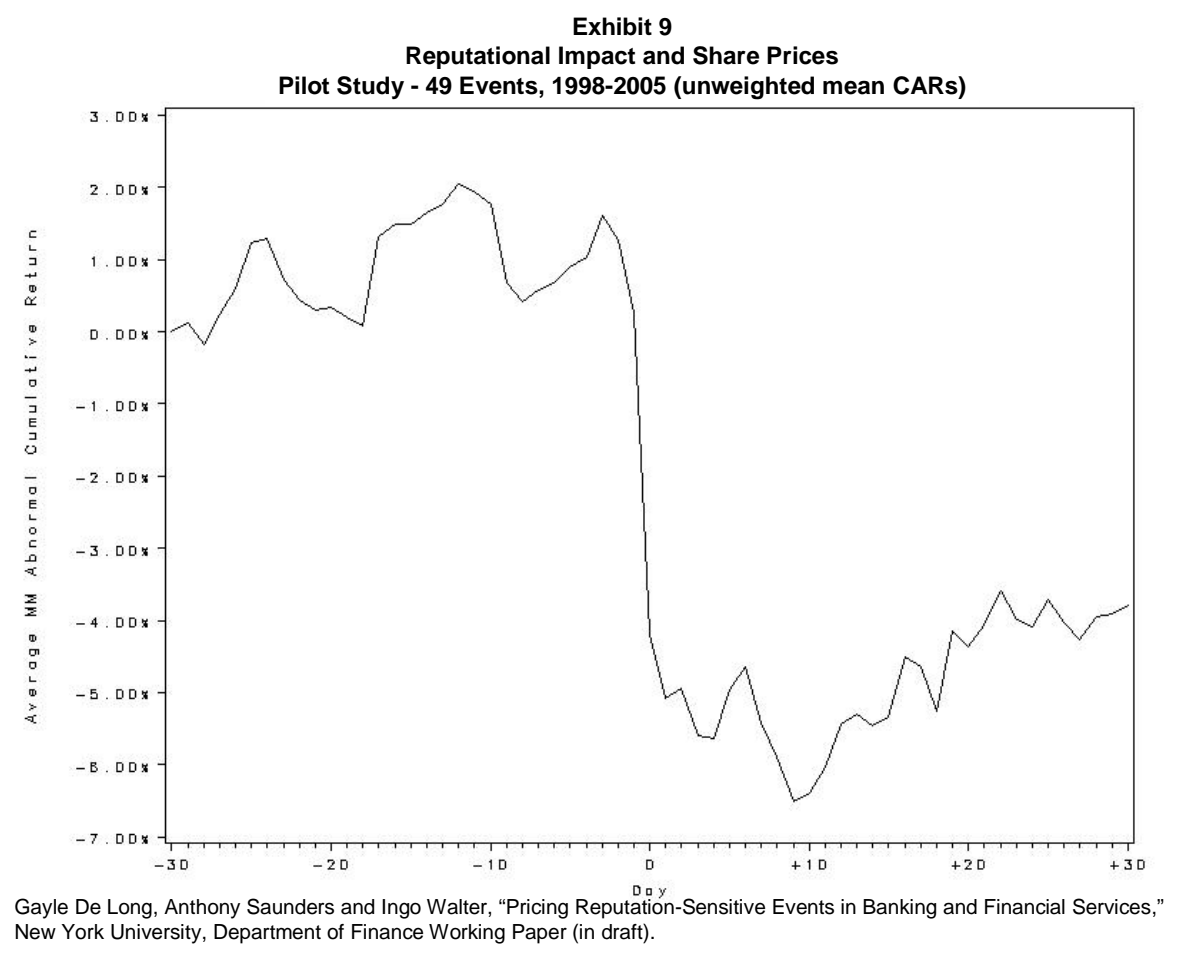

Exhibit 10

Relative CARs - Reputational Loss Pilot Study

Cumulative Abnornal Returns - Statistical Summary

$\begin{array}{lrrrr}\text { Event window } & (-5,3) & (-5,10) & (-1,3) & (-1,10) \\ \text { MEAN } & -6.24 \% & -7.02 \% & -6.79 \% & -7.57 \% \\ \text { Patell Z-score } & -10.02 & -7.63 & -14.37 & -9.41 \\ \text { MEDIAN } & -4.59 \% & -4.92 \% & -4.55 \% & -4.96 \% \\ \text { Bottom 95\% loss } & -38.17 \% & -44.97 \% & -35.88 \% & -44.37 \% \\ \text { Bottom 99\% loss } & -62.57 \% & -47.52 \% & -63.78 \% & -48.73 \% \\ \text { 90\% skew } & -1.0907 & 0.1740 & -1.2563 & 0.0538 \\ \text { 90\% kurtosis } & 0.0696 & -4.6151 & 0.9144 & -4.7431\end{array}$

Gayle De Long, Anthony Saunders and Ingo Walter, "Pricing Reputation-Sensitive Events in Banking and Financial Services," New York University, Department of Finance Working Paper (in draft). 


\section{Reputational Losses in Market Capitalization - Statistical Summary}

Event window

MEAN

p-value

MEDIAN

Bottom 95\% loss

Bottom 99\% loss

$90 \%$ skew

$90 \%$ kurtosis
$(-5,3)$

$-\$ 3,300,009$

0.0000

$-\$ 984,421$

$-\$ 14,875,021$

$-\$ 18,375,026$

$-1.5269$

2.4720
$(-5,10)$

$-\$ 3,485,131$

0.0013

$-\$ 555,256$

$-\$ 24,140,182$

$-\$ 28,360,334$

0.2562

$-0.4915$
$(-1,3)$

$-\$ 1,765,038$

0.0007

$-\$ 700,940$

$-\$ 10,704,029$

$-\$ 13,971,351$

$-0.5088$

0.1960
$(-1,10)$

$-\$ 1,950,161$

0.0049

$-\$ 616,721$

$-\$ 13,227,960$

$-\$ 20,261,036$

$-1.3309$

1.6990

Gayle De Long, Anthony Saunders and Ingo Walter, "Pricing Reputation-Sensitive Events in Banking and Financial Services," New York University, Department of Finance Working Paper (in draft).

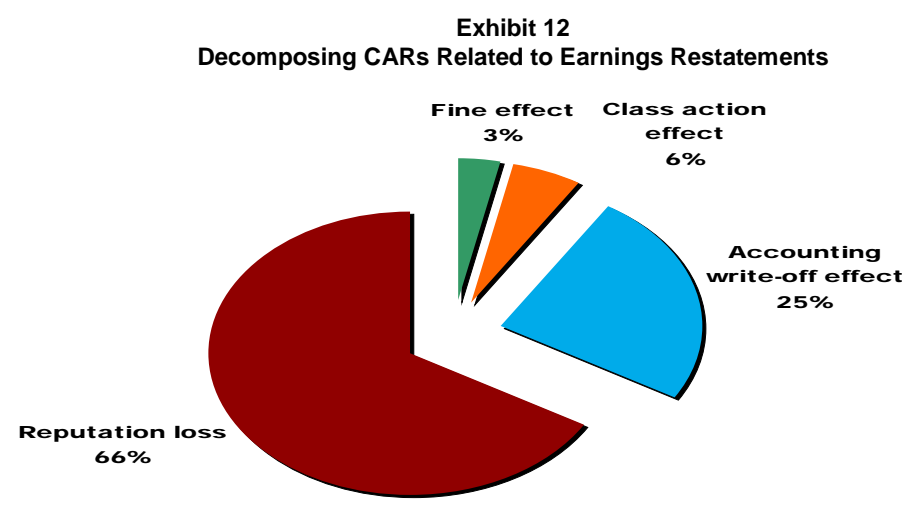

Data: All SEC enforcement actions 1978-2002 - 2,532 regulatory events

Actions \& penalties tracked through 15 November 2005

Mean CAR $-38.06 \%=$ mean market value loss $\$ 397$ million (24\% higher for surviving firms)

Partitioned for sample:

Fines imposed on firms $\$ 5.01$ billion

Class action payments $\$ 8.59$ billion

Accounting write-off $\$ 37.4$ billion

Reputation loss $\$ 101.5$ billion

SourceKarpoff, Jonathan M., Lee, D. Scott and Martin, Gerald S., "The Cost to Firms of Cooking the Books" (March 8, 2006) Available at SSRN: http://ssrn.com/abstract $=652121$ : 
Exhibit 13

Conflict of Interest Domain-Mapping - Wholesale

\begin{tabular}{|l|}
\hline Wholesale Domain \\
Type-1 - Firm-client \\
conflicts. \\
Principal transactions. \\
Abusive tying. \\
Fiduciary violations. \\
Self-dealing. \\
Front-running. \\
\\
Type-2 - Inter-client \\
conflicts. \\
Misuse of information. \\
Client interest incom- \\
patibility.
\end{tabular}

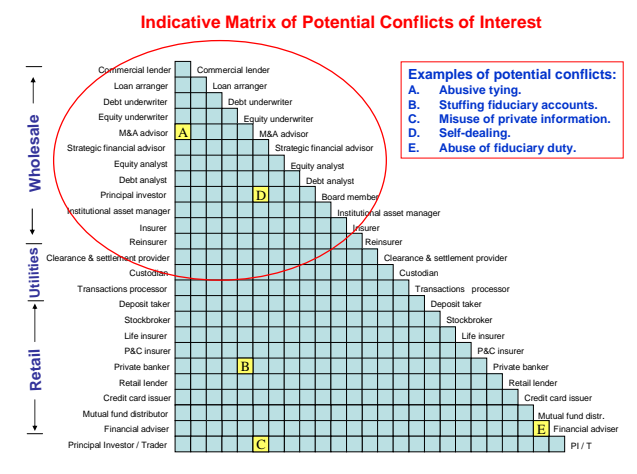

Exhibit 14

Conflict of Interest Domain-Mapping - Retail

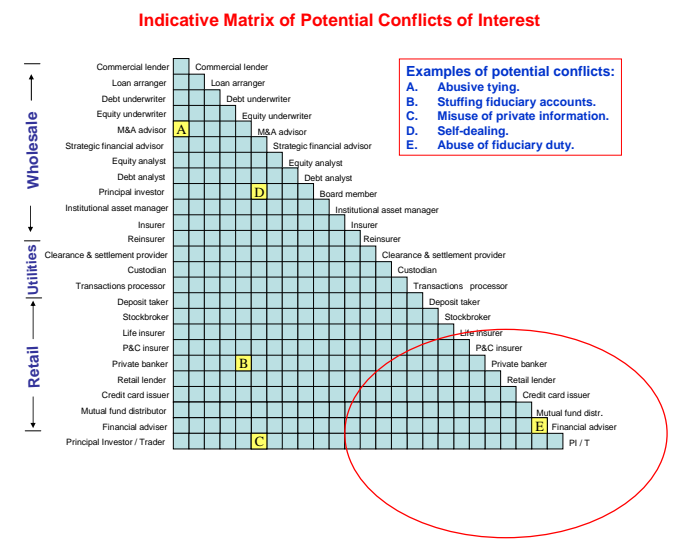

Retail Domain
Type-1 - Firm-client
conflicts.
Biased client advice.
Involuntary cross-selling.
Churning.
Inappropriate margin
lending.
Failure to execute.
Misleading disclosure and
reporting.
Misuse of personal
information.


Exhibit 15

Conflict of Interest Domain-Mapping - Domain-Transition

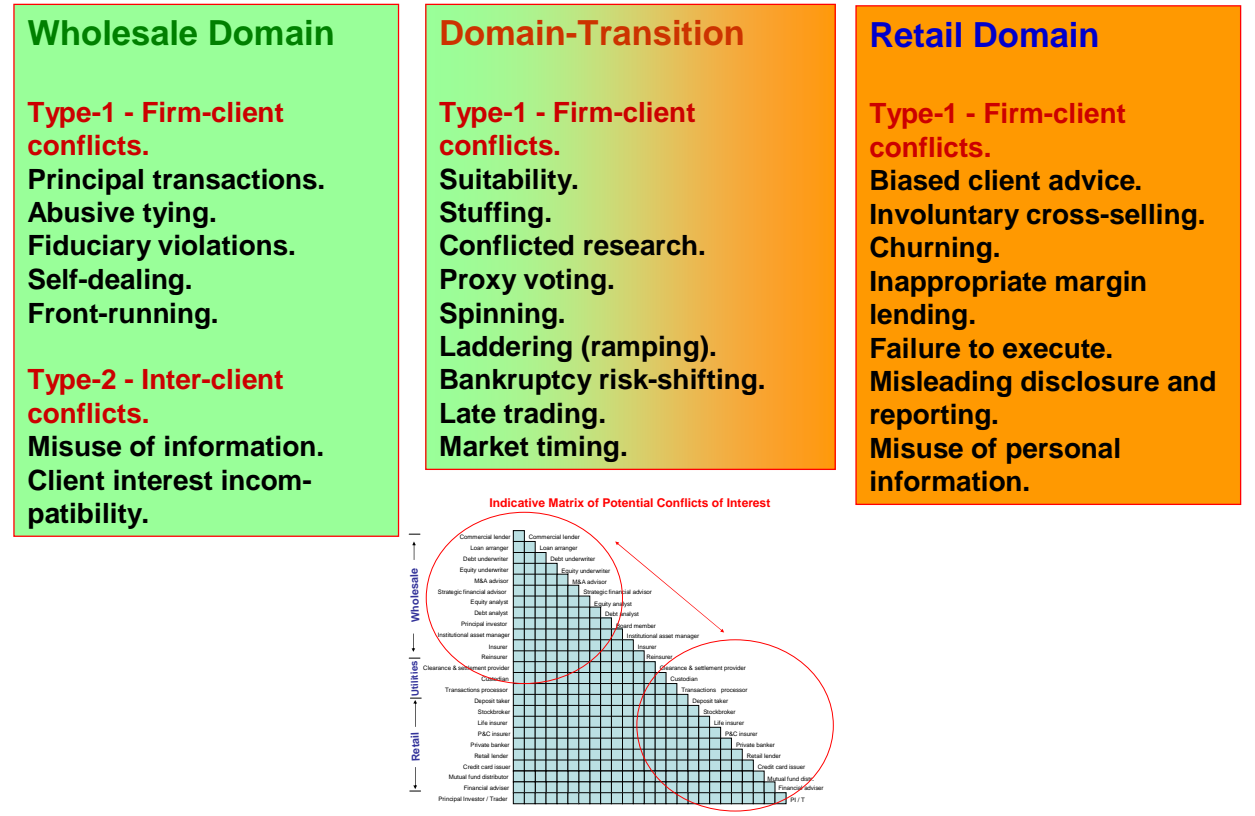

